\title{
Ganti Kerugian Berdasarkan Perjanjian Antara Pengembang Perumahan dengan Konsumen di Atas Tanah Rawan Banjir
}

\author{
Supeno \\ Fakultas Hukum Universitas Batanghari \\ Jalan Slamet Riyadi Broni Kota Jambi Telp: (0741) 65351 \\ Correspondence email: supeno@unbari.ac.id
}

\begin{abstract}
Abstrak. Tujuan dari kajian ini adalah untuk memberikan pemikiran yang kritis terhadap para pengembang perumahan yang membangun perumahan di kawasan banjir yang berdampak menimbulkan kerugian bagi konsumen. Kajian didasarkan maraknya kejadian lahan perumahan yang mengalami banjir pada musim penghujan, kajian dikupas dengan pendekatan peraturan perundangundangan yang berlaku.hasil kajian menunjukkan bahwa belum tercantumnya klausul kewajiban pengembang untuk mengganti kerugian kepada konsumen dalam perjanjian antara pengembang erumahan dengan konsumen jika terjadi banjir di perumahan rawan banjir sehingga konsumen menderita kerugian, hal tersebut bukan merupakan sebagai keadaan memaksa (force majeur) karena untuk dapat dikatakan dalam keadaan terpaksa (force majeur) harus memenuhi unsur-unsur Pasal 1244 KUHPerdata. Untuk memberikan perindungan hukum bagi konsumen maka dari sejak awal pembuatan perjanjian harus dinyatakan bahwa perumahan yang dibeli konsumen berada di lokasi yang aman dari banjir, sehingga jika terjadi banjir konsumen memiliki dasar hukum yang kuat untuk menuntut pengembang. pengembang perumahan harus memmiliki itikad baik untuk melaksanakan perjanjian yang telah dibuat termasuk memberikan ganti kerugian jika terjadi banjir.
\end{abstract}

Kata kunci: perumahan, banjir, keadaan memaksa, ganti kerugian

\begin{abstract}
The purpose of this study is to give critical thinking to the housing developers who build housing in a flood area that impacts the consumer. The study is based on the incidence of residential land that has flooded in the rainy season, the study was peeled with the prevailing regulatory approach. Results show that the developer's obligation has not been included to compensate the consumer in agreement between the developer and the consumer in case of flooding in residential prone to flood so consumers suffer losses, it is not a state of force (force majeur) because to be said in a state of forced (force majeur) must fulfill the elements of article 1244 Civil Code. To provide the protection of the law for consumers, from the beginning of the agreement must be stated that the housing purchased by consumers is in a safe location of flooding, so that if there is a flood of consumers have a strong legal basis to demand developers. Residential developers must have good faith to carry out the agreements that have been made including compensation in the event of a flood.
\end{abstract}

Keywords: housing, flood, force majeure, indemnity

\section{PENDAHULUAN}

Memiliki tempat tinggal merupakan hak dasar yang dimiliki oleh setiap warganegara sebagaimana diatur dalam Pasal 28H Ayat 1 Undang-Undang Dasar 1945 "setiap orang berhak hidup sejahtera lahir dan batin, bertempat tinggal, dan mendapatkan lingkungan hidup yang baik dan sehat serta berhak memperoleh pelayanan kesehatan. ${ }^{1}$ Rumah merupakan kebutuhan dasar bagi manusia, sebagai makhluk yang beradab manusia, rumah merupakan standar kelayakan hidup bagi suatu keluarga untuk mengarungi siklus kehidupan masnusia. Walaupun demikian tidak semua masyarakat mampu untuk membangun rumah dengan biaya sendiri hal ini terjadi karena faktor ekonomi yang mendukung tercapainya keinginan untuk memiliki rumah, tingginya harga tanah menjadi salah satu pemicu sulitnya masyarakat untuk memiliki rumah, di sisi lain begitu pesatnya pertumbuhan masyarakat, maka kesempatan untuk memperoleh rumah juga semakin terbatas, untuk kawasan perkotaan praktis sangat sedikit sekali masyarakat yang memiliki lahan sendiri untuk membuat rumah terutama bagi masyarakat yang berasal dari daerah lain dan masyarakat yang tidak mampu.

Berdasarkan data dari Badan Pusat Statistik Propinsi Jambi pada tahun 2017 penduduk Kota Jambi adalah sebanyak 591.134 jiwa dengan laju pertumbuhan penduduk dari tahun 2016-2017 sebesar 1,31\%, dengan tingkat kepadatan penduduk per $\mathrm{km}^{2}$ sebesar $2.877,18,{ }^{2}$ sedangkan luas wilayah Kota Jambi adalah sekitar 205,38 $\mathrm{km}^{2}$. Menurut data dari Badan Pusat Statistik (BPS) Kota Jambi jumlah penduduk miskin di Kota Jambi tahun 2016 berjumlah 51.61 ribu angka ini lebih kecil dibandingkan tahun 2015 sejumlah 55.51 ribu. Kota Jambi merupakan sasaran utama para pendatang dengan berbagai macam motif terutama mencari pekerjaan, melanjutkan pendidikan, ikut keluarga dan

${ }^{1}$ Pasal 28H Ayat 1 Undang-Undang Dasar 1945.

${ }^{2}$ Badan Pusat Statistik Propinsi Jambi, diakses tanggal 12 Agustus 2019. 
sebagainya, tercatat hingga Juni 2014 ada 2.737 pendatang baru di Kota Jambi dan data per Juni 2015 sudah mencapai 3.411 jiwa sehingga ada peningkatan jumlah pendatang sebanyak 674 jiwa. $^{3}$

Berdasarkan data tersebut diperkirakan akan semakin meningkatnya masyarakat yang membutuhkan hunian, untuk sasaran tempat hunian tidak lagi membeli tanah kosong akan tetapi membeli rumah melalui pengembang dalam kawasan perumahan baik secara cash maupun kredit, dengan alasan karena keterbatasan lahan, terjangkau oleh kondisi ekonomi masyarakat, akses lebih dekat dengan pusat kota dan perbelanjaan, dan tidak perlu memiliki dana awal yang banyak melalui pola kredit pemilikan rumah (KPR). Badan Pusat Statistik Provinsi Jambi mencatat sektor pembangunan property mengalami pertumbuhan tertinggi di Provinsi Jambi, hal ini disebabkan tingginya permintaan konsumen atas perumahan sederhana maupun perumahan mewah sebagaimana dilansir oleh Tribunnews tanggal 6 Nopember 2012, sebagai contoh pada tahun 2015 DPD REI Jambi memasok sebanyak 5.627 unit rumah sederhana tapak (RST). Rumah subsidi untuk masyarakat berpenghasilan rendah (MBR) ini di bangun di Kota Jambi, Muaro Jambi, Sarolangun, Merangin dan Tanjung Jabung Barat, ${ }^{4}$ diprediksi angka ini akan semakin meningkat pada masa yang akan datang karena tingginya tingkat pertumbuhan penduduk berupa pembentukan keluarga baru dan pendatang baru di Kota Jambi.

Di satu sisi hal ini tentu sangat menggembirakan bagi masyarakat yang belum memiliki rumah karena dalam kondisi ekonomi masyarakat sekarang ini masyarakat masih memiliki kesempatan untuk memiliki rumah, akan tetapi di lain sisi ada permasalahan yang sangat mendasar sebagai akibat dari pengembangan perumahan yang besar-besaran tersebut yaitu dampak bagi lingkungan dan tanggung jawab dari pengembang itu sendiri jika terjadi banjir, longsor dan permasalahan lingkungan lainnya. Betapa tidak, dengan semakin terbatasnya lahan yang layak untuk pengembangan perumahan, ada pengembang yang membangun perumahan di daerah-daerah dataran rendah atau yang berada di tepi jurang di mana sebelum dibangunnya perumahan, daerah tersebut merupakan daerah yang selalu terkena banjir pada musim penghujan, hal ini tidak dapat dikatakan sebagai suatu kejadian di luar kesalahan manusia (human error) atau peristiwa force majeur, sehingga ada dua sisi yang mungkin terjadi apakah para pengembang harus bertanggung jawab jika terjadi kerugian materil maupun immaterial yang dialami oleh konsumen perumahan atau para pengembang perumahan tidak bertanggung jawab karena hal ini merupakan peristiwa force majeur.

Okezone pada Tanggal 14 Juni 2017, Kepala Dinas Pemadam Kebakaran dan Penyelamatan Kota Jambi, Ridwan mengatakan banjir akibat tingginya curah hujan yang terjadi sejak selasa malam hingga rabu (14/6/2017) dini hari menggenangi lima kompleks perumahan di kota itu. ${ }^{5}$ Diberitakan juga bahwa banjir rendam 5 kompleks perumahan di Jambi, dari kelima lokasi kompleks tersebut, lokasi yang terparah adalah Perumahan Arwana, Yeyes Lestari dan Namura Indah, pada kanyataannya ketiga lokasi perumahan tersebut terletak di dataran rendah dan sejak awal sebelum dibangun perumahan merupakan daerah rawan banjir. Dampak terjadinya banjir antara lain akan mengakibatkan:

a. Bangunan akan rusak atau hancur akan terjangan air banjir

b. Mengakibatkan korban jiwa

c. Kemacetan lalu lintas

d. Terganggunya aktifitas belajar mengajar di sektor pendidikan

e. Lumpuhnya perekonomian

f. Timbulnya berbagai penyakit (misalnya diare, muntaber, gatal-gatal, dll)

g. Alat-alat rumah tangga mengalami kerusakan

h. Sampai berserakan di mana-mana

i. Lahan pertanian akan puso dan mengakibatkan gagal panen ${ }^{6}$

Fakta tersebut mendorong perlunya dilakukan kajian secara yuridis dan sosiologis apakah pengembang perumahan yang membangun perumahan di atas lahan rawan banjir harus bertanggung jawab atas kerugian yang dialami oleh konsumen.

\section{HASIL DAN PEMBAHASAN}

Berdasarkan ekspose dari World Bank Tahun 2012 yang dimuat dalam Jurnal Pengembangan Kota, banjir merupakan salah satu permasalahan umum yang sering melanda di kawasan perkotaan. Permasalahan banjir di perkotaan menjadi tantangan yang serius, karena dengan kepadatan penduduk yang tinggi dan aset yang lebih besar berada di kawasan perkotaan, maka kerugian yang ditimbulkan juga besar. ${ }^{7}$ Tentang kerugian, banjir juga merupakan bencana yang relatif paling banyak menimbulkan kerugian. Kerugian yang ditimbulkan oleh banjir, terutama kerugian

${ }^{3}$ www.jambiupdate.com, diakses tanggal 22 Februari 2018.

${ }^{4}$ Rumah.com, diakses tanggal 13 Agustus 2019.

${ }^{5}$ News.okezone.com, diakses tanggal 15 Agustus 2019.

${ }^{6}$ Dirwansyah Sesunan, Analisis Kerugian Akibat Banjir di Bandar Lampung, Jurnal Teknik Sipil UBL, Volume 5 Nomor 1 Tahun 2014.

${ }^{7}$ Rizsa Putri Daniati dan Sariffudin, Tingkat Kerentanan Masyarakat Terhadap Bencana Banjir di Perumnas Tlogosari, Kota Semarang, Jurnal Pengambangan Kota (JPK), Volume 3 Nomor 2, 2015. 
tidak langsung, mungkin menempati urutan pertama atau kedua seteah gempa bumi atau Tsunami ${ }^{8}$. Bukan hanya dampak fisik yang diderita oleh masyarakat tetapi juga kerugian non-fisik seperti sekolah diliburkan, kebutuhan barang pokok meningkat, dan kadang-kadang sampai ada yang meninggal dunia. ${ }^{9}$ Pihak yang mengalami kerugian rata-rata adalah masyarakat yang mendiami suatu perumahan yang berada di kawasan rentan banjir, kerugian dapat dialami kapan saja dan kerugiannya dapat dialami berulangkali sehingga perlu adanya ditawarkan konsep ilmiah dan gagasan untuk melindungi kerugian konsumen akibat banjir.

Pasal 1 angka 1 Undang-Undang Nomor 32 Tahun 2009 Tentang Perlindungan dan pengelolaan Lingkungan Hidup mengatur bahwa lingkungan hidup adalah kesatuan ruang dengan semua benda, daya, keadaan, dan makhluk hidup, termasuk manusia dan perilakunya, yang mempengaruhi alam itu sendiri, kelangsungan perikehidupan, dan kesejahteraan manusia serta makhluk hidup lain. Ini merupakan batasan secara limitatif tentang lingkungan hidup yang mencakup sebagaimana yang tertuang dalam pasal tersebut, lingkungan hidup mencakup semua benda termasuk manusia dan perilakunya, apa saja yang dilakukan oleh manusia yang dapat mempengaruhi kelangsungan atau mengganggu ekosistem dan sub-ekosistem terikat dengan undang-undang ini. Pasal 3 huruf g mengatur bahwa tujuan dari perlindungan dan pengelolaan lingkungan hidup bertujuan untuk menjamin pemenuhan dan perlindungan hak atas lingkungan hidup sebagai bagian dari hak asasi manusia, sehingga pemanfaatan lingkungan oleh badan hukum maupun perorangan harus memperhatikan tujuan dari pemanfaatan lahan tanah yaitu harus tetap terjaminnya perlindungan lingkungan hidup terutama yang berkaitan dengan hak-hak dasar manusia seperti kenyamanan, keselamatan hidup dan mendapatkan lingkungan hidup yang baik.

Hal tersebut secara tegas dinyatakan dalam pertimbangan dibentuknya Undang-Undang Nomor 1 Tahun 2011 Tentang Perumahan dan Kawasan Permukiman, bahwa setiap orang berhak hidup sejahtera lahir batin, bertempat tinggal, dan mendapatkan lingkungan hidup yang baik dan sehat yang merupakan kebutuhan dasar manusia, dan yang mempunyai peran yang sangat strategis dalam pembentukan watak serta kepribadian bangsa sebagai salah satu upaya membangun manusia Indonesia seutuhnya, berjati diri, mandiri dan produktif. Adalah suatu hal yang patut dipertanyakan bagaimana mungkin seseorang dikatakan telah mendapatkan keselamatan, lingkungan hidup yang baik dan sehat sedangkan tempat tinggalnya berada dalam kawasan yang rawan banjir. Dalam Pasal 24 Undang-Undang Nomor 1 Tahun 2011 juga mengatur bahwa perencanaan pembangunan rumah dilakukan untuk menciptakan rumah yang layak huni, rumah yang layak huni tidak hanya menyangkut tentang kualitas bangunan, ketersediaan fasilitas rumah yang memadai dan adanya utilitas umum perumahan, akan tetapi rumah yang layak huni juga harus dibangun di daerah yang jauh dari potensi terjadinya banjir sehingga jika pengembang perumahan membangun rumah di kawasan yang rawan banjir dan terbukti di beberapa perumahan yang terkena banjir hal ini mengisyaratkan bahwa rumah tersebut tidak memenuhi syarat layak huni, terutama bagi perumahan komersil yang ditujukan untuk mendapatkan keuntungan, dan pengembang perumahan selayaknya bertanggung jawab terhadap rumah yang terkena dampak banjir berupa ganti kerugian.

Pasal 129 Undang-Undang Nomor 1 Tahun 2011 mengatur tentang hak dan kewajiban, di mana pada huruf e diatur bahwa setiap orang berhak memperoleh penggantian yang layak atas kerugian yang dialami secara langsung sebagai akibat penyelenggaraan perumahan dan kawasan permukiman, tetapi kenyataan di lapangan dapat dikatakan bahwa tidak ada pengembang yang memberi ganti kerugian kepada seseorang yang mengalami banjir, hanya pemerintah maupun lembaga-lembaga keagamaan dan lembaga sosial yang mengulurkan bantuan sukarela kepada keluarga yang mengalami kerugian akibat banjir. Harus difahami bahwa ini tidak dapat dikategorikan sebagai suatu force majeur di luar kesalahan dari seseorang. Menurut J. Satrio, force majeur adalah keadaan yang menghalangi dibitur untuk berprestasi, halangan tersebut timbul di luar salahnya para pihak dalam perjanjian. ${ }^{10}$ Menurut penulis pengembang tidak bisa berlepas diri dari tanggung jawab atas keadaan tersebut karena untuk dapat dikatakan terjadinya keadaan memaksa harus ada usaha yang sungguh-sungguh dari pihak pengembang untuk mengatasi terjadinya banjir, di sisi lain pada dasarnya pengembang sudah mengetahui dengan pasti kondisi lahan yang akan dibangun, apakah berada dalam kawasan bebas banjir atau berada dalam kawasan rawan banjir, kadangkala untuk mendapatkan lahan yang lebih murah secara ekonomi pengembang memaksakan diri untuk membeli lahan tersebut sehingga perumahan yang dibangun sebenarnya tidak layak untuk dijadikan kawasan perumahan.

Hal ini sangat penting adanya peran pemerintah untuk menetapkan suatu syarat bahwa lahan yang diajukan oleh pengembang untuk membangun perumahan adalah kawasan bebas banjir, dengan demikian pemerintah harus menerapkan persyaratan yang ketat terhadap usulan izin yang diajukan pengembang, jika daerah tersebut bebas dari banjir maka dapat dipertimbangkan untuk diberi izin, jika lahan tersebut rawan banjir maka tidak diberikan izin pembangunan perumahan. Oleh karena itu dalam kaitannya dengan hak konsumen untuk mengajukan ganti kerugian ada 2 (dua) posisi yang berbeda, yaitu:

\footnotetext{
${ }^{8}$ BNPB, 2013.
}

${ }^{9}$ Arief Rosyidie, Banjir: Fakta dan Dampaknya, Sera Pengaruh dari Perubahan Guna Lahan, Jurnal Perencanaan Wilayah dan Kota, Volume 24 Nomor 3, Tahun 2013.

${ }^{10}$ J. Satrio, Wanprestasi menurut KUHPerdata, Doktrin dan Jurisprudensi, Citra Aditya Bakti Bandung, 2014. hal. 102 
a. Jika lahan tersebut dari sejak awal berada dalam kawasan bebas banjir, maka pengajuan ganti kerugian tidak dapat dipenuhi karena hal ini murni keadaan memaksa (force majeur) dan banjir tidak diprediksi sebelumnya.

b. Jika lahan tersebut dari sejak awal sebelum dibangun perumahan adalah lahan rawan banjir, maka pengembang harus membuat surat perjanjian dengan konsumen yang menyatakan bahwa lahan perumahan merupakan lahan bebas banjir. Karena dalam keadaan ini adanya unsur kesengajaan dan sudah bisa diprediksi akan mengalami banjir.

Pada huruf $b$, pengembang tidak bisa beralasan bahwa terjadinya banjir karena keadaan memaksa (force majeur) sebab untuk terpenuhinya keadaan memaksa (force majeur) harus terpenuhi unsur-unsur sebagaimana diatur dalam Pasal 1244 KUHPerdata "jika ada alasan untuk itu, si berhutang harus dihukum mengganti biaya, rugi, dan bunga apabila ia tidak dapat membuktikan, bahwa hal tidak atau tidak pada waktu yang tepat dilaksanakannya perikatan itu, disebabkan karena suatu hal yang tidak terduga pun tidak dapat dipertanggungjawabkan padanya, kesemuanya itu pun jika itikad buruk tidaklah ada pada pihaknya"

Menurut Firman Floranta Adonara, Ada 3 (tiga) unsur yang harus dipenuhi untuk terpenuhinya keadaan memaksa (force majeur)

a. tidak memenuhi prestasi;

b. ada sebab yang terletak di luar kesalahan debitur;

c. faktor penyebab itu tidak diduga sebelumnya dan tidak dapat dipertanggungjawabkan kepada debitur ${ }^{11}$

Untuk mengimplementasikan rumah layak huni sebagaimana amanat Pasal 24 Undang-Undang Nomor 1 Tahun 2011 yaitu harus diatur secara tegas dalam klausul perjanjian pembelian perumahan antara pengembang perumahan dengan konsumen, yaitu jika terjadi banjir maka pengembang akan mengganti kerugian yang layak kepada konsumen. Melalui perjanjian para pihak sepakat untuk melakukan hubungan hukum, dengan adanya hubungan hukum tersebut akan menimbulkan akibat hukum bagi kedua belah pihak secara timbal balik dalam arti kedua belah pihak sama-sama mengemban kewajiban dan memiliki hak yang harus dilakukan secara seimbang. ${ }^{12}$ Dengan demikian konsumen memiliki dasar hukum untuk kuat untuk menuntut ganti kerugian berdasarkan kesepakatan yang tertuang dalam perjanjian. Secara yuridis pengembang perumahan dapat dituntut jika terjadi banjir di lahan perumahan dengan syarat dalam klausul perjanjian yang menyatakan bahwa lahan perumahan adalah bebas banjir. ${ }^{13}$ Bahkan menurut Munir Fuadi seseorang itu bisa dipersalahkan di luar kesalahan karena kesengajaan:

"Jika terjadi banjir maka hal tersebut menjadi tanggung jawab mutlak dari pengembang, tanggung jawab mutlak adalah tanggung jawab hukum yang dibebankan kepada perbuatan melawan hukum tanpa melihat apakah yang bersangkutan dalam melakukan perbuatannya itu mempunyai unsur kesalahan atau tidak, dalam hal ini pelakunya dapat dimintakan tanggung jawab secara hukum, meskipun dalam melakukan perbuatannya itu dia tidak melakukannya dengan sengaja dan tidak pula mengandung unsur kelalaian, kekurang-hatian, atau ketidakpatutan". ${ }^{14}$

Oleh karenanya para pengembang tidak dapat begitu saja melepaskan tanggung jawabnya karena alasan keadaan memaksa, karena hal ini termasuk tanggung jawab mutlak (strick liability) para pengembang, di luar adanya unsur kesengajaan, kekuranghatian atau karena ketidakpatutan pengambang tetap dapat diminta pertanggung jawaban karena telah melakukan perbuatan melawan hukum.

Berdasarkan amanat Pasal 84 Undang-Undang Nomor 32 Tahun 2009 diatur bahwa penyelesaian sengketa lingkungan hidup dapat ditempuh melalui pengadilan atau di luar pengadilan, gugatan melalui pengadilan hanya dapat ditempuh apabila upaya penyelesaian sengekata di luar pengadilan yang dipilih dinyatakan tidak berhasil oleh salah satu atau para pihak yang bersengketa, Pasal 85 mengatur kesepakatan yang akan dicapai melalui kesepakatan dapat berupa besarnya ganti rugi sampai tindakan untuk mencegah timbulnya dampak negatif terhadap lingkungan hidup, selain itu konsumen juga dapat menuntut berdasarkan Pasal 8 Undang-Undang Nomor 8 Tahun 1999 Tentang Perlindungan Konsumen, bahwa pelaku usaha dilarang untuk memproduksi atau memperdagangkan barang/atau jasa yang tidak sesuai dengan janji yang dinyatakan dalam label, etiket, keterangan, iklan atau promosi penjualan barang dana tau jasa. Perjanjian antara pengembang perumahan dengan konsumen dapat dikategorikan suatu perjanjian untuk melakukan pekerjaan berupa jasa-jasa tertentu, menurut R. Subekti perjanjian untuk melakukan perkerjaan tertentu suatu pihak menghendaki dari pihak lawannya dilakukan suatu pekerjaan untuk mencapai suatu tujuan, untuk mana ia bersedia membayar upah, sedangkan apa yang akaan dilakukan untuk mencapai tujuan tersebut sama sekali terserah kepada kepada pihak lawan itu. ${ }^{15}$ Dengan demikian konsumen memiliki dasar yang kuat untuk menuntut ganti kerugian jika terjadi kerugian atas terjadinya banjir di lahan perumahan yang dibangun oleh para pengembang.

\footnotetext{
${ }^{11}$ Firman Floranta Adonara, Aspek-Aspek Hukum Perikatan, Mandar Maju Bandung, 2014, hal.67.

${ }^{12}$ Supeno, Dasar-Dasar Hukum Perikatan, Salim Media Indonesia, Jambi, 2019, hal. 19-20.

${ }^{13}$ Hukumonline.com, Perumahan Kena Banjir, bisakah gugat developer?, diakses tanggal 19 Agustus 2019.

${ }^{14}$ Munir Fuady, Perbuatan Melawan Hukum Pendekatan Kontemporer, Citra Aditya Bakti Bandung, 2017, hal. 173.

${ }^{15}$ R. Subekti, Aneka Perjanjian, Citra Aditya Bakti Bandung, 2014, hal. 57-58.
} 


\section{SIMPULAN}

Pengembang perumahan menjalankan bisnisnya merupakan bagian dari kegiatan komersil untuk memperoleh keuntungan dari hasil penjualan rumah dari konsumen, pengembang wajib menyediakan perumahan yang layak huni dalam arti lahan perumahan harus bebas dari banjir, jika perumahan dibangun di lahan rawan banjir maka pengembang harus bertanggung jawab jika terjadi banjir, hal ini tidak bisa dikategorikan sebagai kejadian keadaan memaksa (force majeur) karena untuk dapat dikatakan dalam keadaan memaksa (force majeur) harus memenuhi unsur-unsur menurut Pasal 1244 KUHPerdata, ketentuan tanggung jawab untuk memberi ganti kerugian harus dituangkan dalam perjanjian yang dibuat oleh pengembang dengan konsumen, selain dapat dituntut berdasarkan perjanjian para pihak pengembang dapat diminta tanggungjawabnya berdasarkan alasan perbuatan melawan hukum, di sisi lain perlu diberlakukan persyaratan yang lebih ketat oleh pemerintah sebelum mengeluarkan izin pembangunan perumahan yang diajukan para pengembang.

\section{DAFTAR PUSTAKA}

\section{Buku}

Firman Floranta Adonara. 2014. Aspek-Aspek Hukum Perikatan, Mandar Maju Bandung.

J. Satrio. 2014. Wanprestasi menurut KUHPerdata, Doktrin dan Jurisprudensi, Citra Aditya Bakti Bandung.

Munir Fuady. 2017. Perbuatan Melawan Hukum Pendekatan Kontemporer, Citra Aditya Bakti Bandung.

R. Subekti. 2014. Aneka Perjanjian, Citra Aditya Bakti Bandung.

Supeno. 2019. Dasar-Dasar Hukum Perikatan, Salim Media Indonesia, Jambi.

\section{Jurnal Ilmiah}

Arief Rosyidie, Banjir: Fakta dan Dampaknya, Sera Pengaruh dari Perubahan Guna Lahan, Jurnal Perencanaan Wilayah dan Kota, Volume 24 Nomor 3, Tahun 2013.

Dirwansyah Sesunan, Analisis Kerugian Akibat Banjir di Bandar Lampung, Jurnal Teknik Sipil UBL, Volume 5 Nomor 1 Tahun 2014.

Rizsa Putri Daniati dan Sariffudin, Tingkat Kerentanan Masyarakat Terhadap Bencana Banjir di Perumnas Tlogosari, Kota Semarang, Jurnal Pengambangan Kota (JPK), Volume 3 Nomor 2, Tahun 2015.

\section{Peraturan perundang-Undangan:}

Republik Indonesia, Undang-Undang Nomor 8 Tahun 1999 Tentang Perlindungan Konsumen (Lembaran Negara Republik Indonesia Tahun 1999 Nomor 42)

Republik Indonesia, Undang-Undang Nomor 32 Tahun 2009 Tentang Perlindungan dan Pengelolaan Lingkungan Hidup (Lembaran Negara Republik Indonesia Tahun 2009 Nomor 140)

Republik Indonesia, Undang-Undang Nomor 1 Tahun 2011 Tentang Perumahan (Lembaran Negara Republik Indonesia Tahun 2011 Nomor 7)

\section{Website:}

Badan Pusat Statistik Propinsi Jambi

Hukumonline.com, Perumahan Kena Banjir, bisakah gugat developer?

Rumah.com.

www.jambiupdate.com

News.okezone.com 